\title{
Customised Ibadan-Yoruba
}

\author{
Kolawole Adeniyi and Oluwafemi E. Bamigbade*(Ile-Ife)
}

\begin{abstract}
This article reports that Reverend Gbade Ogunlana, popularly known as Paito wa, uses the Ibadan dialect of Yoruba in his preaching, but deploys available phonological mechanisms to add a sort of comic impression to his speech. Consonant deletion, which is usually minimised in public domains of speaking are rather maximised in his speaking, while tone spreading is accentuated to produce acute rising and falling contours. Further, it is reported that he prefers lexical borrowings which allow him the freedom to then adapt the borrowed words in the layman's manner. This freedom is also apparent in the use of novel words which he is able to pronounce in the layman's manner. It is argued that the intent of these is to add humour to his preaching, and accommodate his target audience for social identity and better understanding, an intention he appears to achieve with his choice of style.
\end{abstract}

\section{$1 \quad$ Introduction}

Yoruba is one of the most widely-studied members of the West Benue-Congo languages. It is spoken predominantly in southwestern Nigeria, as well as in countries such as the Republic of Benin, Togo, and Sierra Leone in Africa, and in Cuba, Brazil and many other non-African countries (Fabunmi 2013). Among its widely varied dialects are Igbomina, Ondo, Ijeșa, OkeOgun, Ibolo, Ife, Yewa, Egba, Ijebu, Awori, Oyo, and Ibadan. The Oyo dialect was the basis of Yoruba standardisation (Fabunmi 2013: 1), but the present-day Standard Yoruba (SY) has diverged so much from the Oyo dialect that it is now regarded as different. Essentially, SY is believed to exist mainly in writing and as a sort of lingua franca within the Yoruba speaking areas. While speaking in public domains, most Yoruba speakers aim at SY, and especially away from their dialects. As a matter of fact, dialectal interference in public domains is often considered an issue to scoff at.

SY has 18 consonants (b, t, d, k, g, kp, gb, j, m, n, f, s, ș, l, r, y, w, h), seven oral vowels (i, e,

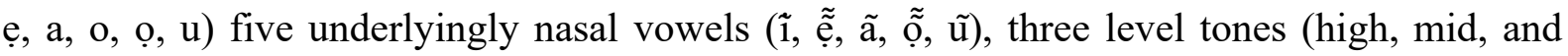
low) and two contour tones (low-rising, and high-falling) (Akinlabi 2004; Adeniyi 2009). Phonetic projections of dialectal variations are usually carried by differing degrees of conformity to these basic components of the SY sound system as well as SY phonotactic. For instance, Ijeșa dialect has many disyllabic nouns starting with /u/ whereas this is prohibited in SY. Similarly, the Ibadan dialect, which is central to this study, lacks $s(/ \delta /$ phoneme) which is

\footnotetext{
* Names of authors are listed in alphabetical order, corresponding author

Linguistik online 80, 1/17 - http://dx.doi.org/10.13092/lo.80.3563
}

CC by 3.0 
present in SY and most other dialects, and many Ibadan people simply substitute this with $\mathrm{s}$ (/s/) even while speaking in public. This is thus the most obvious indication of the dialectal leaning of the Ibadan people.

The aim of this study is to investigate how Reverend Gbade Ogunlana, a public speaker popularly known as Paito wa "our Pastor", deploys this Ibadan dialect in his preaching to obvious effects. Ordinarily, preaching is associated with formality, in which case such processes as vowel elision and consonant deletion are minimised to enhance intelligibility in addition to the use of SY. But besides the use of a dialect in his preachings, Paito wa tends to be a lot informal, eliding vowels, deleting consonants as well as making use of a lot of phonological processes and unusual innovations. Essentially, Paito wa, being a public figure and having his preachings aired on major television stations in Yorubaland, and commanding large viewership and followership (Fabowale 2015), is not expected to deviate from the norm requiring the use of SY in public domains. But that is exactly what he does.

Language is dynamic and individuals usually have their peculiar ways of speaking known as idiolects (cf. Napoli 1996: 296) and this may also play a role in the speaking style of Paito $w a$. Whereas the focus of this article is on the phonological features peculiar to the speech of the subject, we shall not but relate to the non-phonological factors that apparently interact with his phonology.

In the remainder of this article, we supply details about and justification of the popularity of Paito $w a$ in section 2. In section 3 we outline the method of data collection; we present our data, as well as point out issues worth noting in section 4, while further talking points are then brought to section 5 for discussion. The paper is concluded in section 6 .

\section{The Subject: Paito wa}

Reverend Gbade Ogunlana, popularly known as Paito wa to his Nigerian audience, is a 50year old graduate of Agricultural Economics and founder of Gbade Ogunlana Ministries with Headquarters in Ibadan, Oyo State in Southwestern Nigeria. He is a native of Ibadan and is fluent in the Ibadan dialect. Before founding the Gbade Ogunlana Ministries, he had established churches such as Bible City Church in Lagos and People's Church in Ibadan. Paito wa preaches fluently in English and Yoruba on many Television and radio stations in Nigeria. Outside Nigeria, he preaches in South Africa, in the Gambia where he adopts English as medium and his messages are interpreted into Wollof and Fula, and in Senegal where his preachings are interpreted to French. (www.gbadeogunlanaministries.org [01.08.2016]).

\section{$3 \quad$ Methodology}

Data for this study were collected from the public preachings of Paito wa aired on the Broadcasting Corporation of Oyo State (BCOS), Gateway Television (GTV) in Ogun State and Kwara Television, three television stations whose transmissions cut across Yorubaland, and especially on YouTube where he has a large depository of videos of his preachings. Specifically, a total of 15 videos were selected from his YouTube channel as part of the data analysed for this study. These videos were watched with attention on his use of language. Since both authors are competent speakers of Yoruba, and familiar with both SY and Ibadan dialect, identifying variations from SY was not difficult. Also identifying where he adapts the 
Ibadan dialect for various effects (referred to as customisation) in his preachings was not difficult. In addition, the wife of one of the authors was born to an Ibadan mother and raised in Ibadan, hence a competent speaker of the Ibadan dialect and she participated in the threeway discrimination between SY-Ibadan dialect and Paito wa's customised form.

Tonal manipulations were subjected to careful perceptual scrutiny with authors rendering corresponding SY forms for comparison during the course of analyses. Since the preachings are available only in MP4 video formats not readable by Praat, acoustic analyses were not done. This however does not diminish the quality or dependability of data and their analyses since both authors are themselves competent in SY and their intuition as well as exposure was sufficient guide. Besides, although most of the preachings of the subject are done in Ibadan dialect, five of the videos in our corpus (Woli Jemujemu, Eemo lukutu pebe, and Asiri Iya Iyabo oni booli Parts 1-3) were readings of books that he wrote in SY. He also did the readings in SY, which provides a platform for comparison between his use of SY and Ibadan dialect. Usually, the readings were devoid of innovations since prior writing had curtailed his creativity in such cases. But he still succeeds in overlaying contour tone exaggeration on his speech. This then serves as support for the analytical judgements of the authors, since it makes it clear that it is predominantly in the non-reading preachings that he blends innovation and exaggerated phonetic details with his use of Ibadan dialect.

\section{$4 \quad$ Data presentation}

Data studied for this research are presented in this section. In presenting the data, Paito wa's speech forms are labelled "PW" and presented side-by-side with comparative SY forms. This is to allow the reader appreciate the tangible segmental variations between the two forms. These segmental variations include consonant and vowel substitution, consonant deletion, lexical innovations, and borrowings. Tonal manipulations on the other hand, are not as tangible; hence they are described. Since the phonetic environment of these tonal manipulations are straight-forward and always easy to locate in writing, these environments are described such that the reader can appreciate the manipulations. Throughout this article the tone-marking convention of Yoruba is adopted vis. high tone is marked with a superscript acute accent (') on the vowel, the low tone with a superscript grave accent (') and the mid is left unmarked.

\subsection{Consonant deletion}

The preachings of Paito wa usually showcase many phonological processes usual to Yoruba, but deployed to different effects. One of such phonological processes is consonant deletion. In Yoruba, consonants such as $r, w, y, h, l, k, d, t, p, f, s, s, n, b$, and $g$ can be deleted in the flow of speech (cf. Owolabi 2011: 172-174, 201-202). Bamgbose (1990) is specific about the consonant sounds that can be deleted within words being $r, h, w, y$, while others can be deleted in some other positions especially in the grammar of the language. Many of these are observed in the preaching of the subject, beginning from his screen name Paito wa, which derives from Pasito wa via s-deletion, and extending possibly to the verge of absurdity (1-7). Instances of consonant deletion attested in the speech of Paito wa are outlined type-by-type in data sets (1-7). For each utterance in the data a comparative SY form is given below. Many utterances contain multiple instances of consonant deletion and other processes; $(3 \mathrm{~b}-\mathrm{d})$ 
contain both $y$ - and $r$-deletion, in (4a) three consonants $k, s$, and $t$ are deleted while $k$ and $s$ are deleted in (4b). Whereas (7a) contains two instances of $w$-deletion, (7e) also contains two $w$ deletions as well as $k$-deletion. These highlight how extensive consonant deletion is in the speech of the subject. Also worthy of note are the utterances in $(7 \mathrm{a}-\mathrm{f})$ where consonant deletion is in a feeding relationship with vowel lowering; in (7a-f) $w$ is elided, after which ón becomes phonetically lowered to án. The result is wọ́n becoming án.

1) R-deletion
a. PW: lóókọ "in the name of..."
SY: lórúko
b. PW: kékeé "young, small"
SY: kékeré
c. PW: àdúà "prayer"
SY: àdúrà
d. PW: kúò ńbẹ̀-un "leave that place"
SY: kúrò ńbẹyẹn
e. PW: sé Ọlọ́un ọ̀ mọ pộyẹ ọ́ sáànú mi? "Does God not know he should have mercy on me?"

SY: șé Ọlọ́run ò mọ̀ pọ́yẹ kó șáànú mi?

2) K-deletion

a. PW: pẹó tó dé "returns late"

SY: pẹ́ kó tó dé

b. PW: tío tọ́ "that is not right"

SY: tí kò tọ́

c. PW: kè sí n̄tégún èsù ńse téíi pó-un òle fàáọ̀ jó "there is nothing stopping the devil's masquerade from dancing in the morning"

SY: kọ sí ñtégún e șù ń ṣe tí yíó wí póhun kòle fàárọ̀ jó

3) Y-deletion

a. PW: èé ni wí pé "that implies that"

SY: èyí ni wí pé

b. PW: mú ríro î́ kúò "remove this pain"

SY: mú ríro yí kúrò

c. PW: Ẹ fẹ́ kọ́lóun ó bùkún-ín "you want God to bless you"

SY: Ẹ fẹ́ kộlórun bùkún yín

d. PW: Ọlọ́un ńlò-ín "God is using you"

SY: Ọlọ́run ńlò yín 
4) S-deletion

a. PW: wọn èí sábàá fiíbi èyan ó ti mộ-ọn ríi tóbẹeẹ “it is usually not kept where it will be easily seen"

SY: wọn kî́ ṣábà á fi síbi tèyan á ti má-a ríi tóbẹẹ̣

b. PW: òrẹ èyàn lèyàn èé leé dìi nu "it is a friend that one does not keep malice with" $S Y$ : òrẹe èyàn lèyàn kìi lè dì sínú

c. PW: lálá tó bá fòókè "whatever goes up" SY: lálá tó bá fò sókè

5) J-deletion
a. PW: tọeẹ pé "that"
SY: tó jẹ pé

6) W-deletion
a. PW: subú lùá "befall us"
SY: șubú lù wá
b. PW: ẹkọ́ tí mbá kọ́a "whatever lesson I teach us"
SY: ẹ̀kọ tí mo bá kọ́ wa
c. PW: ní lọ̣ọ̣ "have”
SY: ní lộwọ́
d. PW: ó fọmọ ẹ fún-a "he/she gave his/her child to us" SY: ó fọmọ ẹ fún wa

7) W-deletion with vowel lowering
a. PW: bí-án seé fệra-an láyée jộun "how marriage was contracted in those days," SY: bí wọn ṣe ń fẹ́ra wọn láyée jộun
b. PW: Kọ́-an "teach them" SY: kọ́ wọn
c. PW: kẹee báñ ${ }^{1}$ kó-an wá "bring them for me," SY: kẹẹ bá mi kó wọn wá
d. PW: rí-an rẹ́jẹ "succeed in cheating them" $S Y$ : rí wọn rệjẹ
e. PW: Kò sí n tí-án fún-a tó yẹá kọ̀ “there is nothing given to us that we should reject"
SY: Kò sí ntí wọ́n fún wa to yẹ ká kọ
f. PW: tí-án bá láa ní ìsòro kan "if we are said to have a problem" SY: tí wọ́n bá láa ní ìsòro kan

\footnotetext{
1 Tone is usually marked on nasals that are syllabic.
} 


\subsection{Tone spreading}

Further apparent in the preaching of Paito wa is his deployment of the falling and rising contour tones. Yoruba has a surface tone spreading process by which a low tone occurring after a high tone is realised as falling $(/-, / \rightarrow[-\backslash])$ and conversely a high tone occurring after a low tone is realised as a rising tone $(/ \ldots-/ \rightarrow[\ldots /])$ (Cf. Connell/Ladd 1990: 6). Thus either within words or in larger structures on the surface, every low-high (LH) sequence becomes low-rising (L-LH) and every high-low (H-L) becomes high-falling (H-HL) contours respectively. Further, longer sequences in which $\mathrm{L}$ and $\mathrm{H}$ are repeatedly alternated yield longer strings of rise-fall and fall-rise akin to the contour tones of South-East Asian languages. Examples of repeated alternations include igbéyàwó "wedding" a word with LLH-HL-LH tonal sequence and Túbọsún ràwe "Tubosun bought book", a phrase with H-HLLH-HL-LH tonal sequences. All of these are perceptually distinguishable.

A point to note however is that although $\mathrm{H}$ is realised as a rise after $\mathrm{L}$, this rise starts at a level way higher than the preceding L in SY (Fig.1). Conversely, when L falls after H, the fall begins from a level lower that the preceding H (Fig. 2). In the case of Paito wa, the rising tone starts at the same level as the preceding L (Fig. 3) or even lower than it (Fig. 5). On the converse, a falling tone in Paito wa's speech usually starts at the same level as the preceding $\mathrm{H}$ (Fig. 4) or at a level higher that the preceding $\mathrm{H}$ (Fig. 6). This is what is regarded as contour tone exaggeration in this article. In $(1 \mathrm{c}-\mathrm{e}, 2 \mathrm{c}, 3 \mathrm{a}-\mathrm{b}, 4 \mathrm{a}-\mathrm{c}, 6 \mathrm{a}-\mathrm{b})$ the contour tones are exaggerated in this manner, making the rises and falls so conspicuously acute that a comic impression is mingled with his pronunciations.

Fig. 1: $\left[{ }^{\prime}\right] \quad$ Fig. $2:\left[^{-}-\right]$

Fig. 3: $[-/] \quad$ Fig. $4:\left[^{-} \backslash\right]$

Fig. 5: $[-/] \quad$ Fig. $6:\left[^{-\backslash}\right]$

\subsection{Loanword adaptation}

Paito wa uses a lot of direct borrowings from English which are then adapted to the Yoruba phonology (8-19). His borrowings are however often done with certain parts of the phonology exaggerated for stylistic reasons. For instance, in (18-19), he pronounces the /p/ of the borrowed words as in the $/ \widehat{\mathrm{kp}} /$ of Yoruba in such a manner Bamgbose (1990: 80) regards as púrúntù "uneducated layman". Although Yoruba lacks the $/ \mathrm{p} /$ phoneme of the borrowed word, most Yoruba people we know are comfortable pronouncing it once it is in a borrowed word. The exemption to this relates to only some of the people with no formal education at all. Also in (19) he does away with the word-medial nasal and lengthens the preceding vowel to occupy its slot, which further enhances the layman effect. The same thing happens in (10) where, according to Bamgboșe (1990: 81) it would normally have been osipitù. Example (12) however shows that borrowing of this type can be subject to ambiguity, since this can also be read as denoting "test". 
In terms of his deployment of other phonological features in loanword adaptation, there is a question mark on $(8 / 16)$ where the adaptation in (8) should have included an extra low-toned ò immediately after $o ́$ vis kilóòsi; also in (16), the penultimate tone should have been low and not high and the high-toned $\dot{a}$ should have been immediately followed by a low-toned $\grave{a}$ vis dàmáàsikì. As these two words are used, they are examples of marked differences in Paito wa's approach to loanword adaptation in Yoruba and they allow for such sequencing of $\mathrm{H}$ and $\mathrm{L}$ tones that yield exaggerated contours.

While the foregoing may pass as subtle manipulations of the phonology of Ibadan dialect of Yoruba, (15) represents a rather outlandish approach, where he refers to blackberry, a brand of mobile telephone devices as béríbérí. Agreed that he chooses the second part of that word "-berry", adapts it and then reduplicates the adapted form, but questions may still be asked as to how he arrived at bérí since the original tune of that part in English corresponds only to high-low tonal sequence of Yoruba. Note further that by altering the course of adaptation of that form, he ends up with bẹrí a word that means "to behead", and after reduplication, it means "beheader" in Yoruba. If for instance he opted for the alternative bẹribẹrì, he would have ended with an exotic but distinct word to which the meaning of the device could then be attributed. Alternatively, he could have opted for other means of loanword adaptation such as specification, or even adaptation. Instead, he deploys novel segmental and tonal concatenations and reduplication to arrive at a hilarious-sounding word of undesirable semantic content.

Further, some words, exemplified by (11-13) and (15) are not even borrowed into Yoruba in their respective forms; rather Yoruba has its own ways of expressing them. For instance, "clear" is "fara hàn", "text" is borrowed and adapted as "mẹséejil", "durable" is "lálòpèé", "sharp" in terms of ability is "já fáfa" and "mû" in terms of use for cutting. For "blackberry", the generic form "phone" is borrowed and adapted "fóonu".

8) PW: kílósì "close"

SY: kílóòsì

9) PW: sẹ́tùrù "settle"

SY: sẹ́tù

10) PW: ọsibítù "hospital"

SY: ọsipítù

11) kílíà "clear"

12) tẹeẹisi "text"

13) láàsì "last" implying "durable"

14) PW: sẹengì "change"

SY: sệnji

15) bẹ́ríbẹ́rí "blackberry," a brand of mobile telephone devices

16) PW: dàmásíkì "damask"

\section{SY: dàmáàskì}

17) sáfù "sharp" 
18) PW: àpósù "apostle"

\section{SY: àpóstéli}

19) PW: pẹésù "pencil"

\section{SY: pẹ́ńsù}

It is also observable that his borrowings are often done with the intent of deliberately creating a platform for the manipulation of the phonology for comical effects since they are frequently needless. In (20-21), he chose àláwáńsi [àlàáwáńsii] and sínáki [sínákii] respectively and these allow him to accentuate the contour tones for comic effects rather than sticking with ààye "allowance, space" and ìpanu "snack, small chop" respectively, which are typical and easily accessible Yoruba words that will communicate the messages better. We note especially regarding (20) that should the word be adapted in this way, the penultimate syllabic nasal would rather carry a low tone, following the English tune of that section of the word, and not high. But this would have prevented the sort of contour exaggeration he wanted.

The choice of múfù to denote "arouse" in (22) also allows him to pronounce it as [múùfù], but this is clearly not the best option. For one, it is ambiguous, besides, the readily accessible word used to denote this in Yoruba is dide. Also in (23), a word pronounced with exaggerated contour tones vis [èfàáńgélísiì] could have been rendered simply as ajíhìnrere, a regular word that communicates the message better in Yoruba. Besides, notice the use of $/ \mathrm{g} /$ where $/ \mathrm{j} /$ would have been used in typical adaptation of this word to Yoruba in the instance that one does not choose ajihinrere. In speaking, this singular sound alters the perception of the word in a way suitable for his humorous intent. It should be emphasised that although he uses IY, typical Ibadan speakers will still not subscribe to his approach to borrowing and innovations even if they find themselves resorting to the dialect in public.

20) PW: àláwáńsì "allowance"

\section{SY: ààyè}

21) PW: sínákì "snack,"

\section{SY: ipanu}

22) PW: múfù "arouse" derived from "move"

\section{SY: dide}

23) PW: ẹ̀fáńgẹlísì "evangelist"

\section{SY: ajihinrere}

Further limitations to the borrowings and style of Paito $w a$ include the creation of "linguistic exclusion zones within the language" (Awobuluyi 1992: 28). This is because it may be easy for a listener who is familiar with English to subconsciously invoke his (the listener's) knowledge of English to understand words such as láàsi "last" (meaning "durable"), tansukúà "transfer", and sináki "snack", but what about those who do not understand English at all? Such listeners/viewers could be lost as to what these words really mean. 


\subsection{Lexicon}

Also reinforcing the view that Paito wa deploys the phonology of Ibadan dialect of Yoruba for different purposes is his use of novel lexical items pronounced in the layman's manner. He very often uses words that are non-existent in the lexicon of the language. When these novel words contain low-high or high-low tonal sequences as we have in (24-27), he exaggerates the assimilatory effects resulting from the tonal concatenation. While these give him the platform to deploy the available phonetic nuances as desired, they appear to be needless creations. This is because the audience is almost always left wondering what he means; besides, those peculiar words often introduce ambiguity to the message. For instance, in (24) dìláàsì [dìlààsì] denotes "meaning", but Yoruba has the word itumọ which he himself resorted to in order to explain his coinage. kùrátà [kùràátáà] means "troublesome" (25), while it is only suspected that jàgùdàtálí [jàgùdàtàálí] denotes "wife-beater" (26) judging from context. In (27) the reduplicated sequence gíríki gíríki [gíríkiì gìiríkiì] means "cogent", "important". In (28) kólófín is used to denote "mind" whereas okàn is the usual and basic Yoruba word for "mind" and kólọ́fín itself means something else entirely (hiding place). This could be argued as a case of lexical extension, but the problem will remain that it is needless as far as communication is concerned. It can only be logically viewed as innovation for the purpose of achieving humour.

24) PW: kín ni diláàsì àdúà ìgbàgbọ́? "what is the meaning of prayer of faith?”

\section{SY: kín ni ìtumọ àdúrà ìgbàgbọ́?}

25) PW: kùrátà nyyàwó tí mo fẹ́! "my wife is troublesome!"

\section{SY: oní wàhálà nìyàwó tí mo fẹ̣!}

26) PW: ọkọọ mi jàgùdàtálí ni! "my husband is a wife-beater!"

SY: ọkọ̣ mi a máa na aya rẹ̀!

27) PW: kókó gíríkì gíríkì "cogent points,"

\section{SY: kókó pàtàkì}

28) PW: Njộlộun ní-in nì kọ́lọ́fín? "does God have it in mind?”

\section{SY: Ǹjọ́lọ́run ní-in lọ́kàn?}

It should be noted that alternative means of vocabulary augmentation, such as explication, semantic extension, composition etc., exist in Yoruba, but the subject apparently avoids them and sticks with loaning and coinage. This may be due to the attending limitations of these alternatives. According to Bamgboșe $(1992: 4,7)$ the most serious of the limitations is vagueness, by which terms arrived at by explication or other means fail to explicitly state what is intended. Ambiguity is another limitation of the alternative means of vocabulary augmentation by which coined terms may be subjected to differing interpretations. Also, it is only in loaning that the speaker is able to express the ideas in the shortest way. For instance, as easy as explication is, it is bogged with the problem of resulting in too lengthy utterances (cf. Bamgboșe 1992: 7). By opting straight for loaning as shown in section 3.3, the subject is able to express himself clearly while also achieving his humorous overlay. But the coinages exemplified by (24-28) are themselves bogged by the problems of vagueness and ambiguity. 


\section{$5 \quad$ Style and stylistics}

Within the dimension of linguistic variation otherwise referred to as social dimension by Labov (1972), language use shows a kind of social stratification of individuals or groups of individuals within a speech community. It is also observable that there are planes of variations through which individual speakers vary their speaking styles from situation to situation and even from moment to moment. Hence, Coupland and Jaworski (1997: 229) present Halliday's description of two broad kinds of linguistic variation which he classifies as the one based on the user - dialect variation and the one based on use - register or stylistic variation. The need therefore arises to study more closely stylistic variation that is occasioned by who a particular speaker is addressing i. e. "speakers can be expected to adjust to accommodate aspects of their styles towards, or away from, those of their addressees" (Coupland/Jaworski 1997: 229). This model of stylistics is regarded as psychological model since such accommodation is both cognitive and linguistic oriented and also because the model allows a specification of the attitudes which may occasion the speaker to or not to make such linguistic adjustments.

Style is guided by the principle that a speaker has alternatives and choices among which he chooses to speak at a given period of time for certain reasons and to a particular audience type; hence, he does not speak the same way in all occasions. In some sense, these varied choices may bear varied social meanings. Bell (1991) sums it thus: "style involves the way in which the same speaker talks differently on different occasions rather than the way in which different speakers talk differently from each other".

\subsection{Humour}

It is possible for speakers to deliberately exaggerate aspects of the phonology of language for comic effects (cf. Elugbe/Omamor 1991: 66). This strategy is apparent in the preachings of Paito wa, as discussed in section 4 above. But in addition to this, the subject also often resorts to outright jokes for the same purpose. For instance, $(1 \mathrm{a} / 6 \mathrm{a})$ arouse in the listener an outright comic effect. This is because while deleting consonants in such positions is permissible in Yoruba, such expressions as in (1a/6a) are used only when deliberately making jokes and not when one is passing serious information across to the listeners. This humour intent of style choice reflects in his use of the mid-toned "o" particle in the final position of some utterances for stylistic and humour enhancement purposes, and not for its usual emphatic role in speech. In the utterance mo sàkièsí pádúa ií o, òpọo wa la ì gbàá o ... "I notice that many of us do not pray this prayer", this particle is used twice, neither of which denotes emphasis. This is further apparent in (29-30) since in spite of the particle the utterances involved no degree of emphasis. Further in (31-32) he pronounces the utterances in the manner of uneducated laymen, this also adding to the comical dimension of the speech. Also adding to the comical part of his style is the usual lack of the /s/ phoneme in the Ibadan dialect of Yoruba that he adopts for his preachings ${ }^{2}(31-32)$.

\footnotetext{
2 This is a handy means of taunting the Ibadan people, for instance, omọ İbàdàn kín ni sóó... sóò súọ ni, rather than omo İbàdàn kín ni sóò... șóò súọ ni.
}

ISSN $1615-3014$ 
29) PW: a mọ tún dúpẹ́ lọ̣ọ yín o "we thank you again"

SY: a tún dúpẹ́ lộwọ́ ọ yín

30) PW: ẹ jẹá gbàdúà o "let us pray"

SY: ẹ jẹá gbàdúrà

31) PW: rìsáàsì kaàdì "recharge card"

SY: káàdi

32) PW: tansukúa "transfer"

\section{SY: gbé lọ}

Further indications of direct humour in the speech of Paito wa include an instance where he was introducing the topic ìyàtọ láàárín ìgbàgbọ àti ìrètí. "The difference between faith and hope" and commented that somebody might think of a light-skinned person bearing İgbàgbó... and then added jovially that he is not referring to a human being. Also, he said somebody told him that he dreamed of a parcel of land in Indonesia that contained gold... he then interjected that he would not know whether that (Indonesia) is on earth or in heaven. He ended up asking his listeners, "Is it on earth or in heaven?" - a form of rhetorical question.

On another occasion, he was trying to explain that God is impressed when praised, and said olórí gàrí lọlọun, kèi solóríi yanrìn, which literally means the head of God is like gàrí, a local flour made from cassava which rises (in terms of increasing) when soaked in water, as against yanrin "gravel" which does not change state in water. Although this comparison is somewhat demeaning to the person of God, it is outrightly hilarious, in addition to it easily communicating the message.

On why he does not change his name from Ogunlana, a name acknowledging Ogun, the African God of iron, since he is a servant of the God of heaven, Paito wa said that since he was sure that his name was already written in the book of life, he feared that if he changes the name here on earth, heaven may forget to effect the change. All of these are accompanied by smiles and laughter.

\subsection{Stylistic Variation}

Aside the obvious intent of Patio wa to invoke a sense of humour in his preaching style, his deliberate manipulation of phonological nuances presents characteristics of what could be described as stylistic variation - variation according to use. It has been shown that he does not only employ the unnecessary loanwords to replace items with regular equivalents in Yoruba, he also resorts to extensive consonant deletion as well as deliberate use of Ibadan accent in his preaching. Therefore, from the two major possible accommodation strategies - convergence and divergence, the subject's motivation for his deliberate choice of style is made.

The fact remains that, it is possible for him to employ heavy consonant deletion and loanings in his style without typifying Ibadan accent. The mere fact that he includes a familiar accent which is native and 'local' as it were, to the immediate environment is a clear indication of accommodation strategy - a kind of stylistic identity with his immediate audience. This common notion of accommodation as it applies to sociolinguistic analysis explains the 'familiar experience of speakers shifting their accents e. g. from 'broader to 'milder' in the presence of someone speaking a more vernacular or more 'posh' variety (cf. 
Coupland/Jaworski 1997: 229). From his deliberate choice of style, one can imagine his message to the immediate audience, though there may exist some other distant audience who may be moved further apart by reason of his speech mannerisms.

Since within stylistics, interpretation and implementation of linguistic and extra-linguistic devices are done as employed in a communicative discourse, it will therefore not be out of place to establish Paito wa's verbal and non-verbal style within stylistic discourse. This may be based on the semantics, pragmatics, use of pun, coded forms or unconventional speaking style and literary principles. Clearly, within this context, two pragmatic concepts are significant - his message and his style, and each of these could form an agent of accommodation for his listeners. Eight possibilities are therefore identified, where each of the eight possibilities evolve a binary operation for each of the strategies of accommodation convergence and divergence. This is schematically illustrated below;

I.

(A) Message

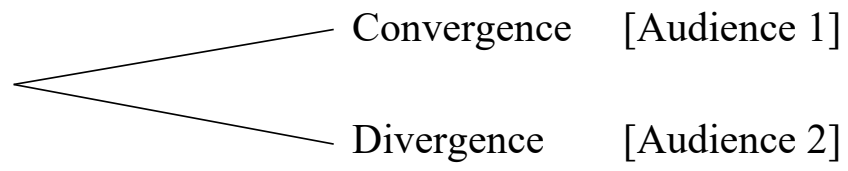

(B)

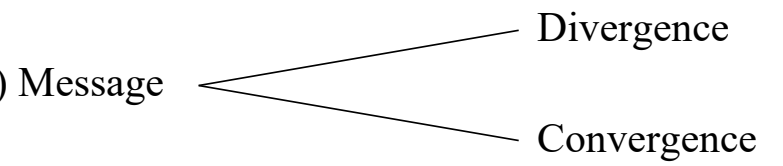

[Audience 1]

[Audience 2]

(C) Message

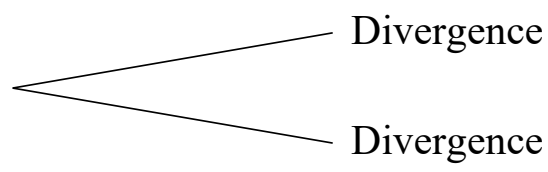

[Audience 1]

[Audience 2]

(D) Message

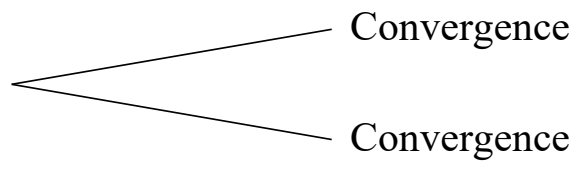

[Audience 1]

[Audience 2]

II.

(A) Style

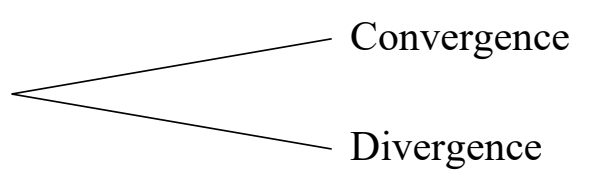

[Audience 1]

[Audience 2]

(B) Style

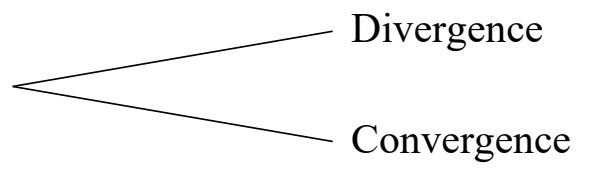

[Audience 1]

[Audience 2] 
(C) Style

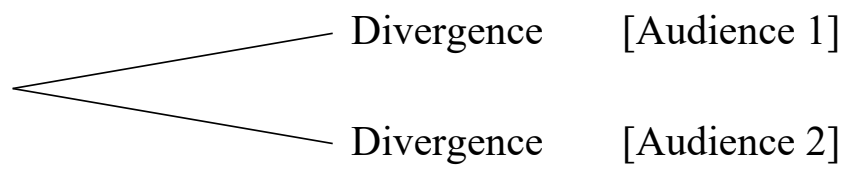

(D) Style

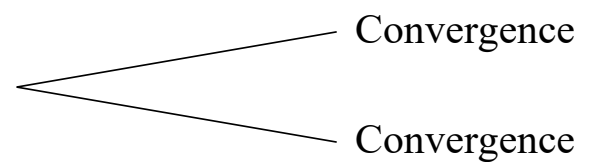

[Audience 1]

[Audience 2]

From the schema above, the two pragmatic concepts of message and style may constitute four binary operations each. One, both could converge with a set of audience [Audience 1] while diverging with some others [audience 2] (Schema IA/IIA), or vice versa (Schema IB/IIB). And otherwise, both could serve as agents of either convergence (Schema ID/IID) or divergence (Schema IC/IIC) for both sets of audience ([Audience 1] and [Audience 2]). Hence, each of these concepts could in different instances with different binarity, either accommodate to or accommodate from one set of audience or both sets of audience.

Most theories of stylistic variation agree that the main motivating principle behind style is the addressee or the audience, though they may differ in approaches of theoretical development. For instance, Giles, Taylor and Bourhis (1973) built a complex psychological theory which identifies speakers' motives and orientations to other speaking participants but also the importance of social norms and the constraints of appropriate behaviour. Bell (1991), on the other hand, works largely within the Labovian tradition, and accounts for statistical data on linguistic variation.

In the same vein, researches in this regards have demonstrated "that an individual's speech patterns are in part dependent on the person to whom he is talking, the topic of the discourse and the setting in which it takes place" (Giles/Powesland 1997: 232). Also, Hymes (1972) notes that code variation and speech diversity have been singled out as a hallmark of sociolinguistics, which is entrenched within the scope of accommodation theory. This hinges on social psychological research on similarity-attraction. It is therefore a known fact that the process of speech accommodation operates on this principle and as such it may reflect an individual's desire for social approval. This social approval may be factored on religion, political, emotional, cultural, ethnic or even race. In the case of Paito wa the choice of style is apparently aimed at fostering accommodation on a religious platform.

\subsection{Accommodation}

It seems that Paito wa's deliberate choice of style presents his intent of accommodation for a social approval/acceptance by his target audience. His target audience is known as he clearly states that he is particularly sent to the Yorùbá race; hence his choice of linguistic and stylistic code. He therefore states that "perhaps your mother/granny came around to help nurse a newborn baby and she does not really understand English, by watching this message on television she would be helped to understand the word of God better". This is a categorical statement on his audience focus (see Adura Igbagbo 'Prayer of faith' [Part 1], İwà Pálapàla nínú Àdúrà 'Abnormalities in Prayer'). In like manner, he explained that he was told in a dream about thirty years earlier, in which he saw himself preaching in Yorùbá, that he had 
been sent particularly to teach the Yorùbá race (see Àlá lílá "Dreaming Dreams" [Part 2]). Within the Yoruba race, he is specific about his being sent to the "downtrodden, the stark illiterates" (Fabowale 2015).

This is a dual role of accommodation - convergence and divergence. By choosing to preach in Ibadan dialect he accommodates to the speech form of the Ibadan people which is a subset of his targeted audience, whereas he seems diverging to his audience who are speakers of other varieties of Yoruba, which the use of such Ibadan phonological nuances may be offensive to. However, this deliberate style helps him achieve his humorous effect on the non-ibadan variety-speaking audience as shall be shown in section 5.4 below.

Apparently, his accommodative act is not without any form of deliberate identity-change and expended effort as price to pay on his part. From his English loan words, one can adduce that he is learned in western education, whereas his style contrasts with this assumption. To do this, a deliberate effort is needed. Contrary to other preachers of his generation, he could have chosen a more dignifying and elaborate platform, vicinity or studio setting as environmental settings for his video shots. He chose various backgrounds associated with natural vegetation, animal skin back-drops and other unconventional costumes such as a dusty floor and streams/riversides (see "Difference between faith and hope", Àwon tí o kò gbudọ fẹ "People you must not marry", Àdúrà İgbàgbọ́ "Prayer of faith" (Part I/II), Àdúrà İṣọkan "Prayer of agreement") as it were, yet for accommodation. These, coupled with his simplicity, are semiotics probably representing his identification with the lowly people in the society. This is a contrast to the highly sophisticated environment that a modern preacher would put in place in a television broadcast.

Clearly, one may assume that the identity presented by the subject is a kind of modification and/or disguise of his social class in a more pragmatic sense. In one of his titles; Àlá lílá (Part 2), he states sarcastically that his spoken English is lowly, because it is said that one should be careful while speaking English to avoid hurting or losing one's teeth - 'bí èèàn bá fẹ kéyín èèàn pé lẹnu, kéèyàn má fèèbó jù'. This he equally reiterates in İwà Pálapàla nínú Àdúrà 'Abnormalities in Prayer' that he does not really have a good grasp of English language. Whereas he has a university degree in Nigeria where English is the medium of instruction in Universities, he is literate. Further on this, the subject has preached a number of message series on air in English language (See "The difference between faith and hope" for instance). This is therefore a clear disguise of his ability and competence in the use of English. The fact that he could preach a complete message for about thirty minutes in English without switching codes is a contrast to his claims of limited command of English. He uses simple day-to-day coherent English, with a sense of humour and clarity using an electronic bible, which to an extent is a semiotic contrast to the status he portends all together. It is also observed that his choice of register and diction, use of tense and his ability to produce some English sounds that are not in Yorùbá such as the voiced and voiceless dental fricatives $/ \theta$, ð/ are quite appropriate (see Paito wa in "Difference between Faith and Hope").

Based on this contradiction, one could surmise that his use of Ibadan phonological variant as a device for humour and as a form of accommodation to low and crude status is context bound - where the context is set exclusively to discourse situations which exclude his English-based and reading-based preachings. Obviously, these phonological nuances are 
maintained absolutely when he employs a free style preaching - a discourse style that is unconventional, non-telly-guided and very non-formal.

When he reads his messages, he is conscious of his speech form and largely conforms to the norms. This is apparent in his series on Àsírí İyá İyábọ oníbọọlì tó kọlé méjì 'The secrete of Iyabo's mother the roast plantain vendor who built two houses' (Parts 1, 2 and 3) and È̀̀mò lukutupẹ́bẹ "Mysterious acts", where he employs a reading medium from a particular literature he had written in standard Yorùbá orthography, where most of these identified customised Ibadan Phonological nuances are conspicuously absent since his presentation is guided by the orthographic form as contained in the text. Whereas, these texts also contain words with labial-velar plosives, he does not accentuate them as he usually does when he is not reading. Accepted, consonant deletion will be minimised in writing, which explains the reason he does not have them in those readings. Hence, such contexts described above betray his disguise.

\subsection{Use of Yoruba in Public Domain}

An observation of the use of Yoruba language in public domains such as religion, education, media etc, characterised by Fishman (1967) as High domain of language use, shows that the target is the use of the standard variety in Yorubaland. Any attempt to use another variety that belongs to a particular sub-group in such domains is considered laughable. In the light of this, the use of Yoruba in ten preaching sessions of Pastor E. A. Adeboye of the Redeemed Christian Church of God are compared with those of Paito wa. Although Adeboye preaches in English, his sermons are always interpreted to Yoruba and the apparent norm is that the interpreters always aim at SY. Also, across most broadcasting stations that broadcast news and magazine programmes in Yoruba, the use of SY is the norm, while the use of various dialects of the language is reserved for comedy and entertainment programmes where humour is essentially needed.

Finding Paito wa using Ibadan dialect to preach in the religious domain and on the mass media for that matter, is therefore an aberration. This is because, in addition to global availability of his sermons on YouTube, his programmes are aired on television stations that broadcast across the seven Yoruba-speaking states of South-western Nigeria (Oyo, Ogun, Lagos, Osun, Ekiti, Ondo, and Kwara). This shows that he is a well-known figure amongst the Christians in the region.

It should be noted that up to half of the Yoruba people are Christians. To this effect, there are several Christian preachers amongst them. However, most of the preachers preach in English, though a good number of them have their sermons interpreted to Yoruba. With Paito wa opting to preach in Yoruba, he carves for himself a niche and quietly amassed wide viewership. Though he is not the only one that preaches in Yoruba, his idiosyncrasies stand him out as being humorous. Another popular Christian preacher who preaches in Yoruba in the region is Pastor Niyi Makanjuola of 'Back to the Bible Ministry' who preaches in standard Yoruba devoid of any deliberate personal mannerism. When Paito wa's style is compared with that of Pastor Niyi Makanjuola, one could conclude that Paito wa deviates from the norm. 
Considering the fact that Paito $w a$ is a native of Ibadan, while Pastor Niyi Makanjuola is from Gbongan; there are dialectal variations between both Ibadan and Gbongan dialects and SY. Whereas Paito wa lends his style majorly to the Ibadan variety with further personal idiolect which customised his speech style, Pastor Niyi Makanjuola has no such influence of Gbongan variety in his speech pattern while preaching let alone any form of personal idiolect. The standard (generally accepted) Yoruba is used by him. Since his style also gained acceptance among the Ibadan people, provides a platform for dialectal identity for them and also attracts the attention of the non-Ibadan Yoruba speakers by reason of humour, Paito wa has become a household name to many and is increasingly extending the reach of his influence. To many Yorubas, a mere mention of Paito wa is automatic reminder of his conspicuously humorous manner of preaching.

\section{Conclusion}

Judging from the discussion thus far, it is evident that Paito wa successfully deploys the nuances of Yoruba phonology, and particularly that of Ibadan dialect of the language, to apparent comical effects. In the long run, his abundant consonant deletion, contour tone exaggeration, and layman's manner of pronouncing certain aspects of the phonetics mark him out as speaking a variety of his own, which is of course based on the Ibadan variety.

Also, there is no doubt that loaning words, especially from English, is the most preferred way of making up for vocabulary deficiency (Bamgboșe 1992: 11), the subject does his loaning with an apparent humorous intent, and more often than not, it is the phonology that projects this intent. By and large, Paito wa is able to achieve a stylistic effect much in the same manner as Chief Zebrudaya in the Nigerian popular radio series, Masquerade (cf. Elugbe/Mgbemena 2007), although Zebrudaya achieved his humour by deliberately breaking the rules of English. On the question of why tonal exaggeration would have humorous effect, it was noted that any deviation from SY in public domain is considered laughable in the Yoruba society. To then deliberately take this beyond mere "slips" and make them conspicuous successfully overlays humour on his entire manner of speaking. Incidentally, he often smiles or even laughs after uttering these deviant forms. Further studies on the speech of this man, especially the social class implications of his speaking, the semantic implications of his innovations among others will be interesting.

It may be argued that the subject is simply speaking his (Ibadan) dialect since he is a native of and is based in Ibadan, and that whatever impression anybody has about his speaking is less important. In this regard, it is crucial to note that whereas Paito wa speaks the Ibadan dialect, he does not just stay at that level, he goes far beyond by exaggerating those peculiar parts of the phonology of the dialect for stylistic effects in his preaching. Corroborating the findings in this article is an interview reported by (Fabowale 2015) in which he said that "God is humorous so it made some of us like that [...] I mix it with a lot of humour" as humour, to him, is one of the best ways of passing God's word across to people. 


\section{Corpus}

Ogunlana, Gbade (2011a): “Adura Igbagbo". YouTube. www.youtube.com/watch?v=hmod2 DsA0rU [10.11.2016].

Ogunlana, Gbade (2011b): "Adura Igbagbo 2". YouTube. www.youtube.com/watch?v=Katbc 2VDwsE [10.11.2016].

Ogunlana, Gbade (2011c): "Adura Isokan". YouTube. www.youtube.com/watch?v=qvzoU YesnxM [10.11.2016].

Ogunlana, Gbade (2011d): "Adura Isokan". YouTube. www.youtube.com/watch?v=SVdBuFKYyw [10.11.2016].

Ogunlana, Gbade (2011e): “Adura Ope". YouTube. www.youtube.com/watch?v=tmtZNnS vCS0 [10.11.2016].

Ogunlana, Gbade (2011f): “Ala Lila”. YouTube. www.youtube.com/watch?v=ZqNp H_G2gVk [10.11.2016].

Ogunlana, Gbade (2011g): “Asiri Iya Iyabo". YouTube. www.youtube.com/watch?v=_FqE ET63qjs [10.11.2016].

Ogunlana, Gbade (2011h): “Awon Ti O Ko Gbudo Fe". YouTube. www.youtube.com/ watch?v=8f2TEKk2L_Q [10.11.2016].

Ogunlana, Gbade (2011i): "Bawo Ni A Se Nmo Eni Ti A Le Fe". YouTube. www.youtube.com/watch?v=itIQ0IvfB7s [10.11.2016].

Ogunlana, Gbade (2011j): "Difference Between Faith and Hope". YouTube. www.youtube.com/watch?v=kcv9YX8S35g [10.11.2016].

Ogunlana, Gbade (2011k): "Eemo Lukutu Pebe". YouTube. www.youtube.com/ watch?v=Muemit53s_I [10.11.2016].

Ogunlana, Gbade (20111): "Iwa Palapala Ninu Adura". YouTube. www.youtube.com/ watch?v=PielrU5DmRA [10.11.2016].

Ogunlana, Gbade (2011m): "Iyato Larin Igbagbo Ati Ireti". YouTube. www.youtube.com/ watch? $\mathrm{v}=\mathrm{sdHj}$ _mbCl8A [10.11.2016].

Ogunlana, Gbade (2014): “Awon Woli Jemujemu”. YouTube. www.youtube.com/ watch?v=9ESr0ZKi6U8 [10.11.2016].

\section{References}

Adeniyi, Kolawole (2009): The Typology of Three-Tone Systems: Ebira, Ghotuo, Yala (Ikom), and Yoruba. Unpublished master's thesis, Department of Linguistics and African Languages, University of Ibadan, Ibadan, Nigeria.

Akinlabi, Akinbiyi (2004): "The sound system of Yoruba". In: Lawal, Nike S./Sadiku, Mathew N. O./Dopamu, Ade (eds.): Understanding life and culture: Yoruba. Trenton N. J., Africa World Press: 453-468.

Awobuluyi, Oladele (1992): "Lexical expansion in Yoruba: techniques and principles". Research in Yoruba language and literature 2: 14-30.

Bamgboṣe, Ayo (1990): Fonólọjì àti girámà Yorùbá. Ibadan: University Press Plc.

Bamgboșe, Ayo (1992): "Corpus planning in Yoruba: the radio as a case study". Research in Yoruba language and literature 2: 1-13. 
Bell, Allan (1991): "Audience Accommodation in the Mass media". In: Giles, Howard/Coupland, Justine (eds.): Contexts of Accommodation - Developments in Applied Sociolinguistics. Cambridge, Cambridge University Press: 69-102.

Connell, Bruce/Ladd, D. Robert (1990): “Aspects of pitch realization in Yoruba”. Phonology 1/7: $1-29$.

Coupland, Nikolas (ed.) (1988): Stylistic Discourse. London: Croom Helm.

Coupland, Nikolas/Giles, Howard. (eds.) (1988): Communicative Accommodation: Recent Developments. Oxford etc.: Pergamon Press. (= Journal of Language and Communication 8/3).

Coupland, Nikolas/Jaworski, Adam (1997): "Stylistic Variation”. In: Coupland, Nikolas/Jaworski, Adam (eds.): Sociolinguistics. New York, St Martin's Press: 229-231.

Elugbe, Ben Ohi/Omamor, Augusta Phil (1991): Nigerian Pidgin: background and prospects. Ibadan: Heinemann Educational Books (Nigeria) Plc.

Elugbe, Ben/Mgbemena, Judith (2007): “Offensive Nigerian English”. In: Ndimele, OzoMekuri (ed.): Convergence: English and Nigerian Languages. Port Harcourt, M\&J Grand Orbit Communications/Emhai Press: 25-50.

Fabowale, Yinka (2015): "Paito Wa's success secrets, by Ogunlana, televangelist". The Sun Newspapers. http://sunnewsonline.com/new/paito-was-success-secrets-by-ogunlana-televa ngelist/ [11.06.2015].

Fábùnmi, Felix Abídèmí (2013): "Negation in sixteen Yoruba dialects". Open journal of modern linguistics 3/1: 1-8.

Finegan, Edward/Biber, Douglas (1994): Perspectives on Register: Situating Register Variation within Sociolinguistics. New York: Oxford University Press.

Giles, Howard/Taylor, Donald M./Bourhis, Richard Y. (1973): "Towards a Theory of Interpersonal Accommodation through Language: Some Canadian Data". Language in Society 2/2: 177-192.

Hymes, Dell (1967): "Models of the Interaction of Language and Social Setting". Journal of Social Issues 23/2: 8-28.

Hymes, Dell (1972): "Models of the Interaction of Language and Social Life". In: Gumperz, John J./Hymes, Dell H. (eds.): Directions in Sociolinguistics: The Ethnography of Communication. New York, Holt, Rinehart/Winston: 35-71.

Labov, William (1972): Sociolinguistic Patterns. Philadelphia: University of Pennsylvania.

Napoli, Donna J. (1996): Linguistics: an introduction. New York: Oxford University Press.

Owolabi, Kola (2011): İjìnlẹ itúpalè èdè Yorùbá I: fònẹtiìkì àti fonólójì. Ibadan: Universal Akada Books Nigeria Limited.

Rickford, John/Eckert, Penelope (eds.) (1997): Style. Cambridge: Cambridge University Press. 